\title{
"A Study of the Gifted Children In Relation To School Atmosphere and Their Academic Achievement"
}

\author{
Dr. M. S.Vijay Kumar, M.A, M.Phil, Ph.D Mrs. R.Suneetha Vijay, M.A, M.Ed., \\ Assistant Professor, Faculty Of Education, Sirte University, Libya. \\ Lecturer, Faculty of Education, St. Francis B.Ed., College, Sevasadana, Koramangala. Bangalore.
}

\begin{abstract}
Some schools appear with warm and pleasant atmosphere where students feel independent. But in some other schools it is hostile and prison like, where students and teachers are in strain at all times. There are schools with good building, play ground, good Library and Laboratory facilities, and they provide many opportunities to the students to participate in activities according to their taste and thus they can develop their talents. On the other hand there are schools where some or all these facilities are denied to the students. Such a difference in the school atmosphere can have serious effects on students, attitude towards schools and their achievement.
\end{abstract}

\section{Introduction}

Education in a society reflects its political philosophy. A democratic society offers an educational opportunity to all children for their maximum development.

The school environment plays an important part in the development of a child. The research findings agree that the school environment, which give healthful satisfaction to the children who maintain a healthy relation with, schools, has a good effect on the development as successful adult. Loree has stressed on environmental influences on learning. The course of learning is influenced by the environmental context within which ongoing learning occurs.

The "Gifted Children" are the future leaders of the world in different fields, such as scientists, poets, artisans, philosophers, political leaders, etc. The progress of any country depends on the opportunity given to their intellectuals for their maximum development. As in the case of other children the environment plays an important part in the development of a gifted child. Gallagher also expresses this idea. The environment can have either an inhibiting or an encouraging effect on the development of intellectually talented. Such an assumption phases a heavy responsibility talented. Such an assumption phases a heavy responsibility of the system. The place of genetics in intelligence, has not been denied, rather the place of environment and its interaction with genetics has been reaffirmed.

Some use the term "gifted" to refer only those highly capable in a wide variety of abilities where as some use it to those who highly competent in any area. Terman used this term to those who have intelligence quotient. In this study, he had taken children with I.Q. above 130 in Stanford - Binet test as "gifted" children. Later this concept was changed and a broader concept was emerged. Thus, Kirk defines, "A gifted child is one who shows consistently remarkable performance in any worthwhile line of endeavour." This definition includes not only intellectually gifted but also one whose performance is consistently remarkable in some potentially valuable activities like music and arts as Witty (1953) defined.

Gulford recommended an intellectual model with three dimension-operation, content and product-and on the basis of it he defined the giftedness. This model yields $120=$ different kinds of mental abilities. Getzels and Jacobson (1962) proposed a two factor theory with intelligence and creativity. In 1968 Calvin W. Taylor grouped talents based on world-of-work needs of specify six important types: academic talent, creative and productive talent, evaluation or decision making talent, forecasting talent, and communication talent.

\section{REVIEW OF LITERATURE}

The study of relevant literature is important in any research method. There are few investigations very similar to the present study. However, the investigator could select literature relevant to his investigation for intense study. They can be divided into two broad categories: (a) related to school environment and (b) related to gifted children.

\section{RELATED TO SCHOOL ENVIRONMENT}

Halpin and Croft (1954) in their study, "THE ORGANIZATIONAL CLIMATE OF SCHOOLS", sought to identify the domain of organizational climate and to describe it. They constructed an "Organizational Climate Description Questionnaire" (OCDQ) to portray the organizational climate of a school. It is composed of sixty four items which teachers and principals can use to describe the climate to their schools. The eight sub- 
tests of OCDQ pertain to characteristics of the faculty as a group and principal as a leader. They are Disengagement, Hindrance, Esprit, Intimacy, Aloofness, Production, Emphasis, Thrust, and Consideration. This questionnaire was administrated in Seventy-One elementary schools in United States. By factor analysing the profiles for these schools, the investigators identified six types of organizational climates, which is a continuumopen, Autonomous, controlled, Familiar, Parental and Closed.

The investigation conducted by Anila Shani which was named as "SCHOOL ORGANIZATIONAL CLIMATE AND SCHOOL ACHIEVEMENT IN SECONDARY SCHOOL IN DELHI" was aimed to study the organizational climate of three private and three central schools of Delhi. The investigator tried to find-out the organizational climate of these two sets of schools and its relationship with achievement of the students. To collect the data she used the OCDQ developed by Halpin and Croft. The results of this study indicate that the organizational climate of the schools did not exhibit any group pattern. Each school with in the two groups had different climates. The organizational climate is significantly related to the student achievement. The schools which were having "Open" and Antoniou-climate were found to have significantly high achievement index as compared with "controlled" climate.

Amarnath's (1980) "COMPARATIVE STUDY OF THE ORGANIZATIONAL CLIMATE OF GOVERNMENT AND PRIVATELY MANAGED HIGHER SECONDARY SCHOOLS IN JULLUNDAR DISTRICT" was conducted in thirty-two higher secondary schools. The principals and nine teachers from each school were included in the sample. The data collected with the help of OCDQ by Halpin and Croft. The mean scores of the result of Higher Secondary Part" examinations were taken for the academic achievement of the students. The two major findings, which are relevant to our study, are given below:

(a) The government and privately managed schools, as a group, did not differ significantly in their organizational climate, but differed from school and no two schools had similar organizational climate.

(b) There was no positive relationship between the organizational climate and the academic achievement of the students.

\section{Results}

In the view of these studies we can conclude that I.Q. score obtained from, the administration of a standardized intelligence test is the best one method of identification of gifted children. The school environmental conditions have an effect on the achievement of gifted children.

\section{Materials And Tools}

The success of an investigation greatly depends on the selection of appropriate tools. The present investigator tried him best to find out most useful tools for the study.

- A device to measure different aspect of schools environment.

- An intelligence test to identify the gifted children and are to control the factor of intelligence.

- An achievement test to measure the academic achievement of VIII and IX classes students. The tools, which were selected, are described below.

- Some of the important ideas, which are drawn from this study, are as given below.

- 1. At-least certain aspects of physical social and psychological aspects of environment for learning are important to the educational process.

- 2. The site plan and the surrounding atmosphere of a school are important. Its building size and shape are also have an effect on functioning of the school. It is found that governments have given guideline about the size and shape of classrooms and facilities to be provided in it.

- 3. Over emphasize on intellectual drill may fail to stimulate the social abilities such as co-operation, Socialization self-control and group organization. The Co curricular activities or generally know as extracurricular activities promote interest in school by providing opportunities for developing individual interest and aptitude. Thus psychological as well Social needs of the child can be managed through Students Associations, School Assembly, Athletics and games, Cultural activities etc. It may also develop healthful competition and self-discipline. Students should be encouraged to work in groups and to accept group responsibilities for the welfare of the school and its programmes. For an active child it gives satisfaction and may affect his/her education.

- 4. The facilities provided in a school as library facilities, well equipped laboratories have their effect on the achievement of students. In the studies of Coleman and his associates (1966) found that in combination with other forces for intellectual pursuit facilities can have some effect on the environment of the school.

- 5. The three main sources of knowledge are nature, society and books, Nature and society give first hand experience. This can be acquired though the project excursions and involvement in social activities. The books (in broad same the terms 'Book' include the audio visual equipments such a films and photograph in 
addition with the what we usually mean) provide a vest amount of knowledge which can't be experienced due to disadvantage of distance and time.

\section{PROPOSED RESEARCH WORK}

The normal classrooms organized according to the needs of average children, some times, prevent the maximum development of the exceptional children. Therefore, they require modification of school practice or educational services. The needs of backward/handicapped children in India have been recognized and provisions have been made for them though not satisfactorily. But the gifted children are often grown with lack of opportunity for their maximum development. This results into a huge national wastage of talents and the consequent dearth of leadership in different fields. In this context, the warning of whitehead is remarkable. In the modern world the rule is absolute any which does not value trained intelligence is doomed."

\section{Conclusion \& Future Work}

From the foregoing discussion, we can come to the following conclusions:

The variation in school environment has an effect in academic achievement of gifted children.

The classroom situation is more important than other aspects of school environment. But the physical environment and Para-curricular activities have some effect on academic achievement of gifted children.

Authoritarianism in schools lowers the academic achievement of gifted children.

The school with better environment in general has better academic achievement of gifted children.

\section{SUGGESTIONS FOR FURTHER STUDY}

The investigator is of the view that following studies can be fruitfully made by future researchers:

1) The effect of identification and grouping of gifted children is schools to their academic achievement.

2) To study relationship between teachers experience and special training and the achievement of gifted children.

3) To find out the effect of environmental factors on gifted children as well as normal children.

4) The relationship between the achievement of gifted children and the attitude of adults, viz. teachers, parents, elder relatives, towards them.

\section{References}

[1]. Agrawal, J.C. (1976), "EDUCATIONAL ADMINISTRATION" Delhi.

[2]. Ahmad, Nasim, (1986) "INFLUENCE OF ENVIRONMENTAL CONDITIONS IN LEARNING: A STUDY OF SECONDARY SCHOOL STUDENTS", M. Phil dissertation, Jamia Millia Isllamia.

[3]. Amarnath, (1980), "COMPARATIVE STUDY OF THE ORGANIZATIONAL CLIMAT OF GOVERNMENT AND PRIVATELY MANAGED HIGHER SECONDARY SCHOOL IN JULLANDER DISTRICT" Ph. D Dissertation, Punjab University.

[4]. Anastasi, Anne (1983) "PSYCHOLOGICAL TESTING" (Fifth Edition) New York: Macmillan Publishing Co. Inc.

[5]. Anila, Shani (1973) "PHYCHOLOGICAL CLIMATE AND SCHOOL ACHIEVEMENT IN SECONDARY SCHOOL IN DELHI" M. Ed. Dissertation, Jamia Millaia Isllamia.

[6]. Anderson, K. E. al, (1961): RESEARCH ON THE ACADEMICALLY TEALENTED STUDENT" Washington D.C., N.E. A of U.S.

[7]. Aparna Tickoo and Hussain, M.G. (1986), "PSYCHOLSOCIAL CORRELATES OF GIFTEDNESS" Jamia Millia Islamia.

[8]. Barbe, W.B. (1963), "ONE IN A THOUSAND: A COMPARATIVE STUDY OF HIGHLY AND MODERATELY GIFTED ELEMENTARY SCHOOL CHILDREN": Ohio, Stat Board of Education.

[9]. Best, J.W. (1982); "RESEARCH IN EDUCATION" (FIFTH EDITION) New Delhi: Prentice Hall of India Pvt. Ltd.

[10]. Bhatnagar, R. P. and Agrawa, V (1986); Educational Ad ministration (2nd Edition), Meerut: Loyal Book Depot.

[11]. Bloom, B.S. Hasting, J.T. et. al. (1971), "HEAD BOOK ON FORMATIVE AND SUMMATIVE EDUCATION OF STUDENT LEARNING, Me Graw Hill book Company.

[12]. Bloom, B.S. (1979) "TEXONOMUY OF EDUCATIONAL OBJECTIVES BOOK-1 CONGITIVE DOMAIN", London; Longman group Ltd.

[13]. Bryan, J.N. (1963) "BUILDING A PROGRAMME FOR SUPERIOR AND TALENTED HIGH SCHOOL STUDENTS." S.T.S. Project, North Central Association, Chicago.

[14]. Buch, M.B. (Ed.) "THIRD SURVEY OF RESERCH IN EDUCATION, 1978-83, New Delhi: NCERT

[15]. Burt, S.C, "THE GIFTED CHILD", New York: John Wiley \& Sons, Inc., 1975. 